\title{
Comparative study of influence of fetal bovine serum and serum of adult rat on cultivation of newborn rat neural cells
}

\author{
A. N. Sukach ${ }^{1,2}$, M. V. Shevchenko', T. D. Liashenko \\ ${ }^{1}$ Institute for Problems of Cryobiology and Cryomedicine, NAS of Ukraine \\ 23, Pereyaslavskaya Str., Kharkiv, Ukraine, 61015 \\ ${ }^{2}$ G. S. Skovoroda Kharkiv National Pedagogical University \\ 29, Artema Str., Kharkiv, Ukraine, 61002 \\ an_sukach@yahoo.co.uk
}

\begin{abstract}
Aim. To study the influence of fetal bovine serum and serum of adult rats on behavior of newborn rat isolated neural cells during their cultivation in vitro. Methods. The isolation of neural cells from neonatal rat brain. The determination of the dynamics of cellular monolayer formation. Immunocytochemical staining of cells for $\beta$-tubulin III, nestin and vimentin. Results. It has been determined that the addition of serum of adult rats to the cultivation medium creates more favorable conditions for survival, attachment and spread of differentiated, and proliferation of the stem/progenitor neural cells of newborn rats during cultivation in vitro compared with the fetal bovine serum. Conclusions. Using the serum of adult rats is preferable for the cultivation of isolated neural cells of newborn rats compared with the fetal bovine serum.
\end{abstract}

Keywords: newborn rat neural cells, newborn rats, cultivation, fetal bovine serum, adult rats serum.

Introduction. For the successful survival and functioning of isolated cells in vitro it is necessary to create the conditions as close as possible to those in which the cells were in vivo. For this purpose the culture media commonly used should provide the cells with nutrients, as well as hormonal and regulatory factors, $i$. e. with everything necessary for cell growth and survival [1]. In general, all culture media are saline solutions of certain composition with an addition of the components of biological origin with obscure composition (plasma, serum, tissue extracts, etc.) [1-3] or synthetic additives [4]. However, the vast majority of cells are capable of proliferation and differentiation only in the media that contain natural supplements.

As a source of such additives the serum is often used [5]. It is a highly complex mixture of small and large molecules that can both stimulate and inhibit the growth of cells [6]. The serum is a source of hormonal

(C) Institute of Molecular Biology and Genetics, NAS of Ukraine, 2014 factors, which stimulate the growth of cells and ensure their functioning, as well as growth factors that specifically stimulate cell division, factors of cells attachment and spreading; minerals, lipids, transport proteins for hormones, etc.

It is considered that the majority of mammalian cells preferably grow in the presence of bovine serum, which is prepared from either embryos, or newborn animals. However, due to the large variability of the composition [7], the use of different batches of serum requires preliminary testing their ability to support the growth of primary cultures and cell lines. Besides, some sera turn out to be toxic, causing binding and degeneration of cells. On the other hand, when using the serum of newborn calf for the cultivation of animal and human cells it is necessary to take into consideration the existence of interspecies differences in the composition of sera. Such differences provide the specificity of development and functioning and they depend on the conditions of environment [8]. 
The aim of the work was to study an effect of the presence of fetal bovine serum (FBS) and adult rat serum (ARS) on the behavior of isolated neural cells (NC) of newborn rats at their cultivation in vitro.

Materials and methods. $\mathrm{NC}$ were isolated from the brain tissue of newborn rat. The brain tissue was incubated in sterile $0.25 \%$ solution of trypsin for $5 \mathrm{~min}$, transferred to the sterile DMEM/F 12 medium, containing $10 \%$ of rat serum and mechanically disaggregated into a single cell suspension [9]. The resulting cell suspension was filtered through a nylon filter and washed by centrifugation at $1500 \mathrm{r} / \mathrm{min}$. The cells precipitate was resuspended in DMEM/F-12 culture medium, containing $10 \%$ of rat serum.

Cell viability was evaluated by $0.4 \%$ trypan blue («Sigma», USA) exclusion [10]. The cell concentration was counted by Neubauer hemocytometer.

The cells were cultured at a concentration of $2 \cdot 10^{6}$ cells $/ \mathrm{ml}$ in 24-well plastic plates («Corning», USA) in the DMEM/F12 («Sigma») medium, supplemented with $0.6 \%$ glucose, $2 \mathrm{mM}$ glutamine, $3 \mathrm{mM}$ sodium bicarbonate in the presence of either $10 \%$ ARS, or $10 \%$ FBS produced by three different manufacturers: «Biolot» (Russia), «Sigma» (USA) and «Gold» (PAA, Austria). $100 \mathrm{units} / \mathrm{ml}$ of penicillin and $100 \mu \mathrm{g} / \mathrm{ml}$ of streptomycin were added to the medium. The culturing of cells was carried out in a $\mathrm{CO}_{2}$ incubator at a constant gas environment $\left(5 \% \mathrm{CO}_{2}\right.$ and $95 \%$ air) at $37^{\circ} \mathrm{C}$. The culture medium was changed every 3-4 days.

The microscopic analysis was carried out on the light inverted microscope (AmScope MT3000, USA)

The dynamics of monolayer forming was defined by the assessment of resizing monolayer area in the process of cultivation.

The morphometric measurements were performed using the software AmScope (USA).

The immunocytochemistry was performed after the preliminary fixation of the cell cultures with $4 \%$ paraformaldehyde in phosphate-buffered saline. In the cultures the presence of specific marker proteins was determined: neurons - $\beta$-tubulin III; neural stem cells nestin; neural progenitor cells - vimentin. The used primary antibodies were: mouse monoclonal to $\beta$-tubulin III («Sigma»), mouse monoclonal to nestin («Abcam», UK) and rabbit polyclonal to vimentin («Abcam»). The used secondary antibodies were: chromeo 546 goat an- ti-mouse («Abcam»), chromeo 488 goat anti-rabbit («Abcam»). The cell nuclei were stained by Hoechst 33342 («Sigma $)$.

The photomicrography of the stained cell cultures was made on microscope Observer Z1 («Carl Zeiss», Germany).

To obtain the serum the white adult outbred rats were decapitated under ether anesthesia. The collected blood was placed in a refrigerator for $15 \mathrm{~min}$ to activate coagulation. The clotted blood was centrifuged at $3000 \mathrm{r} / \mathrm{min}$ for $15 \mathrm{~min}$ in OPN-3 centrifuge. The resulting serum was sterilized by filtration through a filter with a pore diameter $0.22 \mu \mathrm{m}$ («Millipore», USA), aliquoted and stored at $-18^{\circ} \mathrm{C}$.

The results were statistically processed by Student's $t$-test using the program MS Excel.

The experiments were conducted in accordance with the «General Principles of Animal Experiments», approved by the III National Congress on Bioethics (Kyiv, 2007) and consistent with the provisions of the «European Convention for the Protection of Vertebrate Animals used for Experimental and other Scientific Purposes» (Strasbourg, 1986).

Results and discussion. In 1960 Moscona for the first time demonstrated the formation of aggregates by dissociated $\mathrm{NC}$ during their cultivation, these aggregates possessed certain characteristics of intact tissue [11]. The procedure of cell aggregation, developed by Moscona, was based on the rotary cultivation [11]. We studied the spontaneous formation of aggregates by $\mathrm{NC}$ in the presence of ARS and FBS, the size, density of cells packaging and shape of which correlated with the survival and behavior of cells in culture in vitro $[12,13]$.

The viability of freshly isolated $\mathrm{NC}$ of newborn rats, determined by staining with trypan blue vital dye, was $30-70 \%$.

The culturing of $\mathrm{NC}$ of newborn rats in the enriched serum free DMEM/F12 medium was characterized by the attaching and spreading of a small amount of individual cells that were characterized by a glial morphology. In the process of further cultivation the proliferation was not observed, the cells did not form the monolayer and eventually died.

When NC were cultured in the presence of ARS or FBS, the forming of free-floating multicellular aggregates was observed within a few hours after seeding (Fig. 


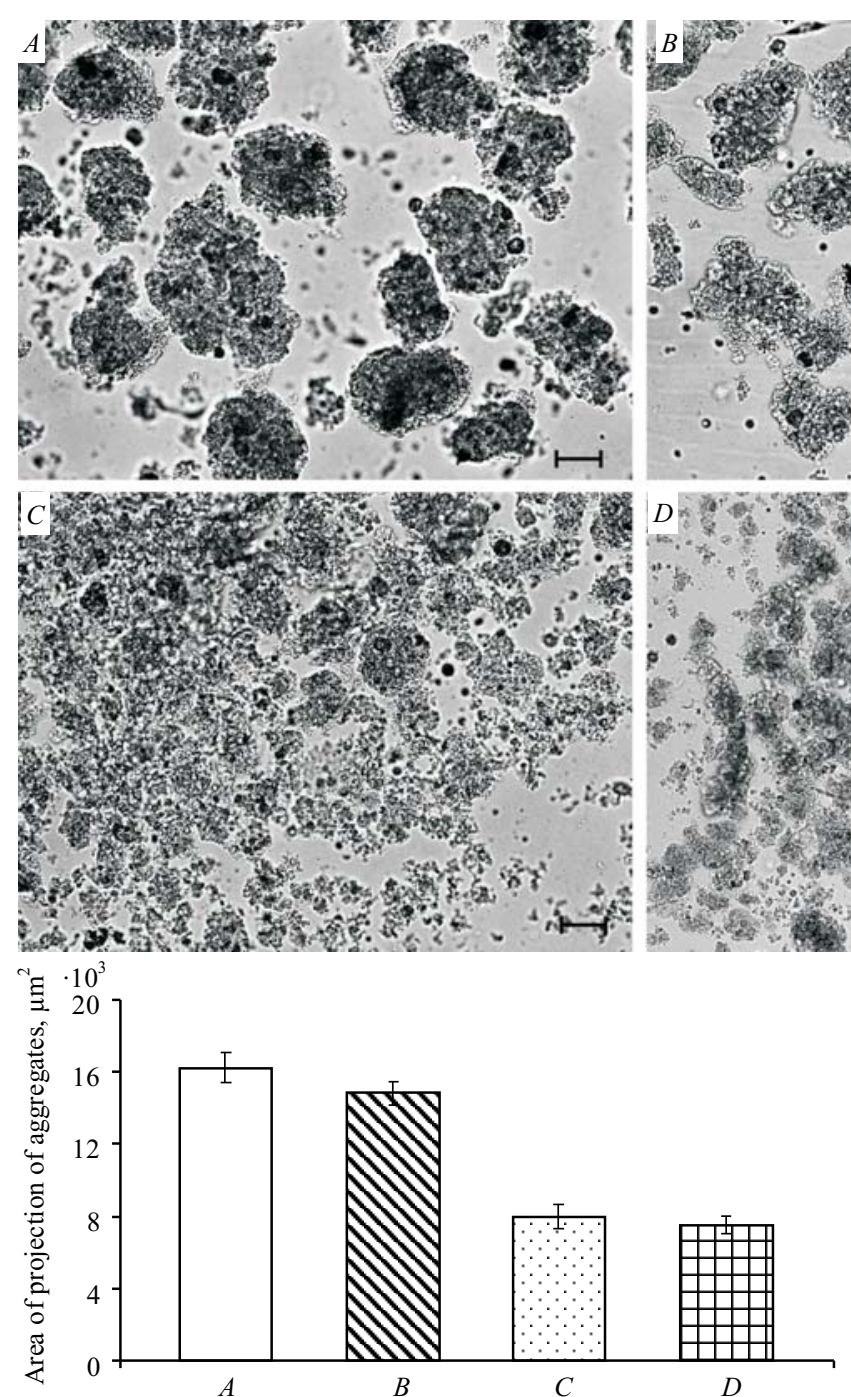

Fig. 2. Size dependence of multicellular aggregates, which are formed during cultivation of NC in the presence of ARS $(A)$ and FBS: «Sigma» $(B)$, Gold» $(C)$ and «Biolot» $(D)$

1). No pronounced dependence of the shape, size and density of the formed aggregates on the initial cell viability was revealed.

However, as it can be seen in Fig. 1 and 2, the size of the aggregates and their number depended on the species affiliation of the used serum and its manufacturer. Thus, in the presence of ARS and FBS («Sigma») the projected area of formed aggregates was twice as big as that of the aggregates, formed in the presence of FBS manufactured by «Gold» and «Biolot» (Fig. 2). The aggregates, formed in the presence of ARS, appeared to be more contrast compared with the aggregates, formed in the presence of FBS («Sigma «) (Fig. 1), suggesting a denser packing of cells in them.
Fig. 1. The aggregates forming within $6 \mathrm{~h}$ of cultivation of freshly isolated suspension of $\mathrm{NC}$ of newborn rats in DMEM/F12 medium in the presence of $\operatorname{ARS}(A)$ and FBS: «Sigma» $(B)$, «old» $(C)$ and «Biolot» $(D)$. Scale bar: $50 \mu \mathrm{m}$

When cultured in the media, enriched with ARS and FBS («Sigma» and «Gold»), the NC aggregates increased in size by merging. During further cultivation a part of aggregates acquired a spherical shape - about $30 \%$ in the presence of ARS and about $10 \%$ - in the presence of FBS («Sigma») (Fig. 3). When NC were cultured with FBS manufactured by Gold and Biolot, the forming of dense spherical aggregates (spheroids) was not observed.

During further cultivation the $\mathrm{NC}$ aggregates and spheroids began to attach to the substrate. The efficiency of their attachment also varied depending on the species-specific serum. When NC were cultured in the presence of ARS, about $95 \%$ of the aggregates attached to the substrate within two days of cultivation (Table).

In the medium, enriched with FBS («Sigma»), about $80 \%$ of aggregates attached to the substrate on the $3^{\text {rd }}$ day of cultivation (Table). In the media, enriched with FBS («Biolot» and «Gold»), about $75 \%$ of aggregates attached to the substrate on the $5^{\text {th }}$ day of cultivation (Table). The cells of the attached aggregates migrated and spread forming the monolayer areas (Fig. 4, A). The cells were characterized by glial and neuronal morphology (Fig. 4, A). The cells with neuronal morphology were $\beta$-tubulin III-positive. They were located on 

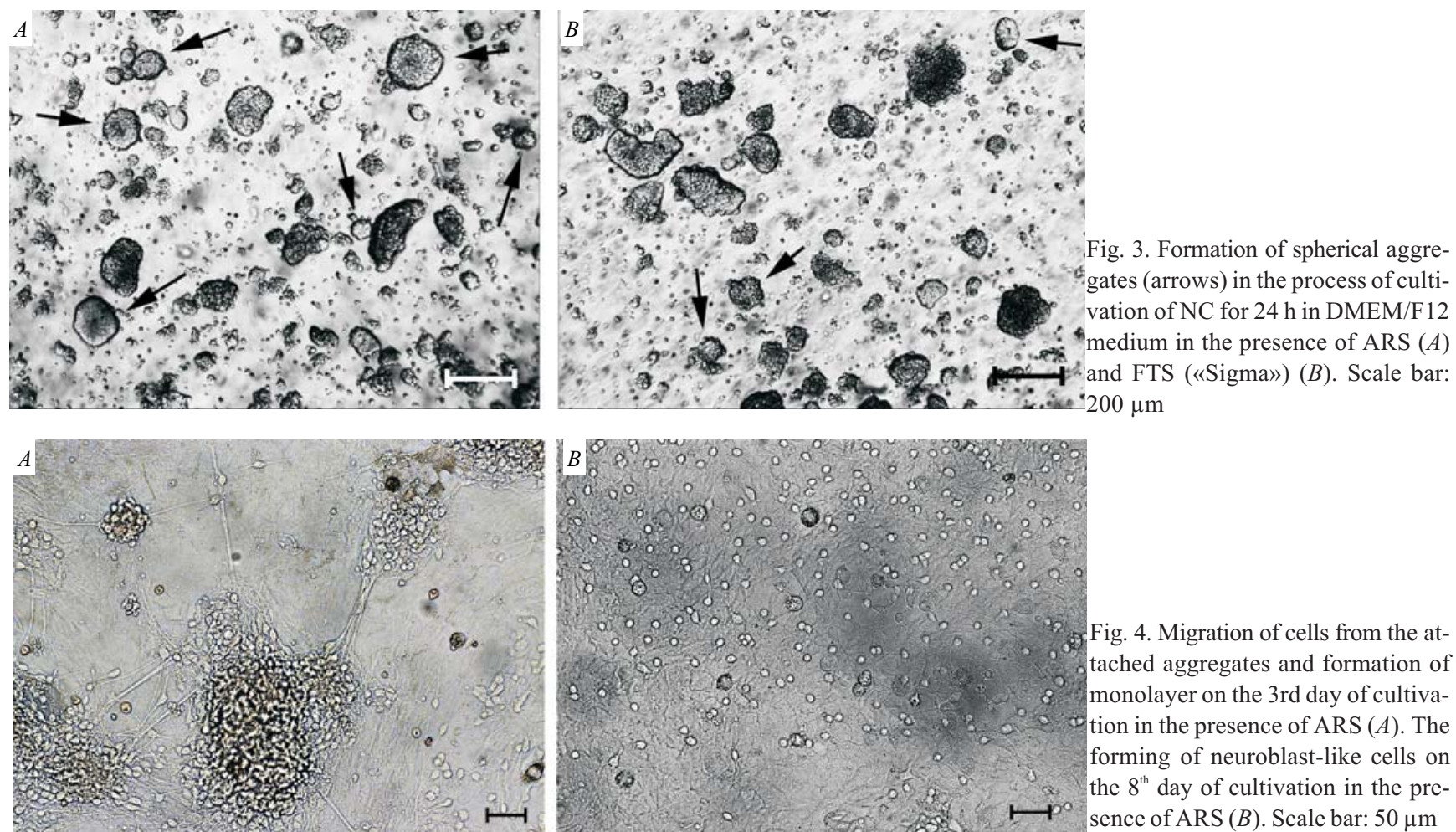

Fig. 4. Migration of cells from the attached aggregates and formation of monolayer on the 3 rd day of cultivation in the presence of ARS $(A)$. The forming of neuroblast-like cells on the $8^{\text {th }}$ day of cultivation in the presence of ARS $(B)$. Scale bar: $50 \mu \mathrm{m}$

Effect of different sera on the stages of cultivation of NC aggregates

\begin{tabular}{c|c|c|c|c|c}
\hline \multirow{2}{*}{ Culture medium } & \multicolumn{5}{c}{ Stages of cultivation of NC, days } \\
\cline { 2 - 6 } & $\begin{array}{c}\text { Start of aggregate } \\
\text { attachment }\end{array}$ & Dynamics of aggregate attachment & $\begin{array}{c}\text { Start of formation of } \\
\text { monolayer by NC }\end{array}$ & $\begin{array}{c}\text { Appearance } \\
\text { of neuroblasts }\end{array}$ & $\begin{array}{c}\text { NC colony } \\
\text { formation }\end{array}$ \\
\hline DMEM/F12 + ARS & $1-2$ & $4(95 \%$ of aggregates $)$ & 2 & $4-6$ & 11 \\
DMEM/F12 + FBS («Sigma», USA) & 3 & $6(80 \%$ of aggregates $)$ & 4 & 6 & - \\
DMEM/F12 + FBS («Gold», PAA, Austria) & 5 & $7(75 \%$ of aggregates $)$ & 5 & 7 & - \\
DMEM/F12 +FBS («Biolot», Russia) & 5 & $7(75 \%$ of aggregates $)$ & 5 & 7 \\
\hline
\end{tabular}

the surface of glial monolayer and formed the cellular network by means of the processes shown in Fig. 5.

The rate of monolayer formation also depended on the type of serum. When cultured in the medium, enriched with ARS, the monolayer areas appeared on the second day of cultivation (Table). On the $4^{\text {th }}$ day of cultivation the monolayer occupied about $80 \%$ of the substrate, the cells with morphology of neuroblasts appeared on it (Fig. 4, B).

In the medium, enriched with FBS («Sigma»), the monolayer areas appeared on the $4^{\text {th }}$ day of cultivation. On the $11^{\text {th }}$ day of cultivation the monolayer occupied about $80 \%$ of the substrate. The appearance of cells with neuroblast morphology was observed on the $6^{\text {th }}$ day of cultivation (Table).
In the medium, enriched with FBS («Biolot» and «Gold»), the monolayer areas appeared on the $5^{\text {th }}$ day of cultivation. On the $13^{\text {th }}$ day of cultivation the monolayer occupied about $80 \%$ of the substrate. The cells with the morphology of neuroblasts appeared on the $7^{\text {th }}$ day of cultivation.

During the further cultivation the number of neuroblast-like cells increased in the presence of ARS or FBS of all manufacturers. However, the most intense increase in their number was observed in the presence of ARS. On the $8^{\text {th }}$ day of cultivation the neuroblast-like cells were observed on $80 \%$ of monolayer. When cultured in the presence of FBS («Sigma») the neuroblast-like cells were found on $80 \%$ of the monolayer surface on the $11^{\text {th }}$ day of cultivation. The density of the cells was 

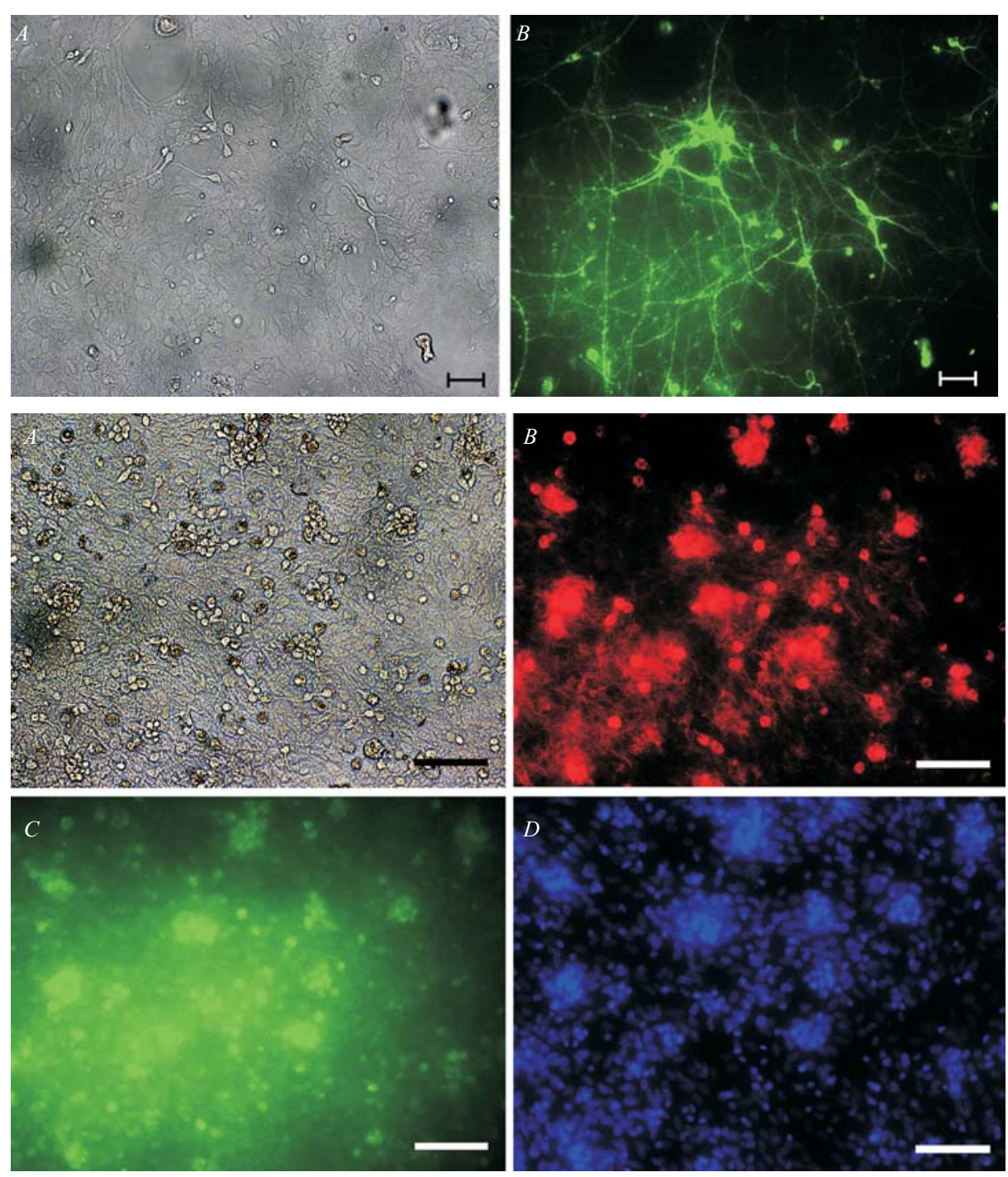

Fig. 5. Immunocytochemical staining of NC from newborn rats with antibodies to $\beta$-tubulin III after monolayer formation: $A$ - before and $B$ - after staining. Scale bar: $50 \mu \mathrm{m}$ lower than that in the presence of ARS. In the presence of FBS («Biolot» and «Gold») the cells with the morphology of neuroblasts were observed on $30 \%$ of the monolayer surface on the $13^{\text {th }}$ day of cultivation.

On the $11^{\text {th }}$ day of cultivation in the medium enriched with ARS, the colonies of vimentin- and nestinpositive undifferentiated cells appeared on the monolayer of glial cells (Fig. 6) whereas no colonies were observed in the FBS-enriched media, regardless of the manufacturer. These data, on the one hand, indicate the presence of stem/progenitor cells in suspension of newborn rat brain tissue, and on the other hand they show that, unlike to FBS, the ARS presence stimulates the cells proliferation during the cultivation.

Thus, our research shows that the presence of serum in culture medium is required for successful cultivation of heterogeneous suspension of NC of newborn rats. Moreover, the results of research demonstrated the dependence of survival efficiency, attachment and spreading of differentiated cells and proliferation of stem/progenitor $\mathrm{NC}$ on the species-specific characteristics of serum.

The findings show that, regardless of the sera manufacturer, the use of ARS for cultivation creates more favorable conditions, compared with FBS, for the effective functioning of terminally differentiated, committed and stem/progenitor NC under in vitro conditions. Apparently, just the ARS supplements the culture medium with specific growth factors, proteins, hormones and other biologically active substances in optimal qualitative and quantitative interrelation. Furthermore, the FBS probably does not contain at all or contains insufficient amount of the factors that cause (or promote) the proli- 
feration of neural stem/progenitor cells. It is indicated by the failure of the formation of colonies of stem/progenitor cells during the cultivation of newborn rats $\mathrm{NC}$ in the presence of FBS. Actually Artiodactyla, which include calves, phylogenetically are quite far from rodents, including rats, and this affects the qualitative and quantitative composition of their blood serum [8]. Moreover, the serum composition may also be affected by habitat conditions of species, which are essentially different for calves and rats.

Conclusions. The addition of the serum of adult rats to the culture medium creates more favorable conditions for the survival, attachment and spreading of differentiated cells and proliferation of the stem/progenitor $\mathrm{NC}$ of newborn rats during in vitro cultivation compared with the fetal bovine serum.

Порівняльне дослідження впливу фетальної сироватки телят і сироватки дорослих щурів на культивування нервових клітин новонароджених щурів

О. М. Сукач, М. В. Шевченко, Т. Д. Ляшенко

Резюме

Мета. Вивчення впливу фетальної сироватки телят і сироватки дорослих щурів на поведінку ізольованих нервових клітин новонароджених щурів при культивуванні. Методи. Виділення нервових клітин з головного мозку новонароджених щурів; культивування; визначення динаміки утворення моношару клітин; імуноичитохімічне фарбування клітин на присутсність $\beta$-тубуліну III, нестину і віментину. Результати. Встановлено, що додавання сироватки дорослих шурів до середовища культивування створює сприятливіші умови для виживання, прикріплення і розпластування диференційованих клітин, а також проліферації стовбурових/прогеніторних нервових клітин новонароджених щурів у процесі культивування in vitro порівняно з внесенням фетальної сироватки телят. Висновки. Використання сироватки дорослих щурів є прийнятнішим при культивуванні ізольованих нервових клітин новонароджених щурів, ніж фетальної сироватки телят.

Ключові слова: нервові клітини, новонароджені щури, культивування, фетальна сироватка телят, сироватка крові дорослих uурів.

Сравнительное исследование влияния фетальной сыворотки телят и сыворотки взрослых крыс на культивирование нервных клеток новорожденных крыс

А. Н. Сукач, М. В. Шевченко, Т. Д. Ляшенко

Резюме

Цель. Изучение влияния фетальной сыворотки телят и сыворотки взрослых крыс на поведение изолированных нервных клеток новорожденных крыс при культивировании in vitro. Meтоды. Bbделение нервных клеток из головного мозга новорожденных крыс, культивирование; определение динамики образования монослоя клеток; иммуночитохимическое окрашивание клеток на присутствие $\beta$-тубулина III, нестина и виментина. Результаты. Установлено, что добавление сыворотки взрослых крыс в среду культивирования создает более благоприятные условия для выживания, прикрепления и распластывания дифференцированных клеток, а также для пролиферации стволовых/прогениторных нервных клеток новорожденных крыс в процессе культивирования іп vitro по сравнению с внесением фетальной сывороткой телят. Выводы. Использование сыворотки взросльх крыс более предпочтительно при культивировании изолированных нервных клеток новорожденных крыс, чем фетальной сыворотки телят.

Ключевые слова: нервные клетки, новорожденные крысы, культивирование, фетальная сыворотка телят, сыворотка крови взросльх крыс.

\section{REFERENCES}

1. Masters $J R W$. Animal Cell Culture. A Practical Approach. $3^{\text {rd }}$ Ed. Oxford University Press, 2000; 315 p.

2. Pajtler K, Bohrer A, Maurer J, Schorle H, Schramm A, Eggert A, Schulte $J H$. Production of chick embryo extract for the cultivation of murine neural crest stem cells. J Vis Exp. 2010;(45). pii: 2380 .

3. Rauch C, Feifel E, Amann EM, Spotl HP, Schennach H, Pfaller $W$, Gstraunthaler $G$. Alternatives to the use of fetal bovine serum: human platelet lysates as a serum substitute in cell culture media. ALTEX. 2011;28(4):305-16.

4. Gstraunthaler $G$. Alternatives to the use of fetal bovine serum: serum-free cell culture. ALTEX. 2003;20(4):275-81.

5. Davis J. M. Basic Cell Culture. A Practical Approach. $2^{\text {nd }} E d . O x-$ ford University Press, 2002; 381 p.

6. van der ValkJ, Mellor D, Brands R, Fischer R, Gruber F, Gstraunthaler G, Hellebrekers L, Hyllner J, Jonker FH, Prieto P, Thalen $M$, Baumans $V$. The humane collection of fetal bovine serum and possibilities for serum-free cell and tissue culture. Toxicol In Vitro. 2004;18(1):1-12.

7. Price PJ, Gregory EA. Relationship between in vitro growth promotion and biophysical and biochemical properties of the serum supplement. In Vitro. 1982;18(6):576-84.

8. Obukhova LM, Deryugina AV, Nikiforova ON. Species differences in vertebrate blood serum structural macroportrait. Vestnik of Lobachevsky State University of Nizhni Novgorod. 2011; 2(2):287-93.

9. Petrenko $A Y u$, Sukach $A N$. Isolation of intact mitochondria and hepatocytes using vibration. Anal Biochem. 1991;194(2):326-9.

10. Seglen PO. Preparation of isolated rat liver cells. Methods Cell Biol. 1976;13:29-83.

11. Moscona A. Rotation-mediated histogenetic aggregation of dissociated cells. A quantifiable approach to cell interactions in vitro. Exp Cell Res. 1961;22:455-75.

12. Sukach AN. Characteristics of human embryonic neuronal cells obtained by non-enzyme method. Tsitologiia. 2005;47(3):207-13.

13. Sukach AN, Liashenko TD, Shevchenko MV. Properties of isolated neural cells from newborn rat tissue in vitro. Biotechnologia Acta. 2013;6(3):63-8. 